\title{
Improved Blood Sample Processing for PCR
}

\author{
Domenic Casareale, Ravi Pottathil, and Robert Diaco
}

Roche Molecular Systems-A Subsidiary of Hoffmann-La Roche, Branchburg, New Jersey 08876-1760

To simplify our procedure for blood sample processing for PCR, we introduced a simpler, shorter, and more cost-effective method for the separation of peripheral blood lymphocytes (PBL) and DNA extraction for amplification with Taq polymerase. By this method, blood samples are processed in two simple 15-min steps: (1) separation of PBLs from whole blood by red blood cell lysis with the Roche Specimen Washing Solution, and (2) DNA extraction by heat-detergent treatment of separated PBLs. This new method is simpler than the standard Ficoll-Hypaque method for PBLs separation and Proteinase $K$ digestion for DNA extraction. It is not inhibitory to DNA amplification and it allows effective processing of blood samples even after prolonged storage (as long as 8 days) at room temperature. he $\mathrm{PCR}^{(1)}$ is a highly sensitive test for the detection of viral DNA in peripheral blood leukocytes (PBLs) and a potentially powerful tool in the laboratory diagnosis of infectious diseases for which peripheral blood is frequently the specimen of choice. In cases where the infectious agent is known to have tropism for lymphocytes, separation of the lymphocytes from whole blood and DNA extraction are necessary steps prior to testing by PCR. The traditional method for the separation of PBLs from whole blood is the Ficoll-Hypaque gradient centrifugation method ${ }^{(2,3)}$; the DNA is extracted by Proteinase $\mathrm{K}(\mathrm{PK})$ digestion $^{(4)}$ followed by the phenol-chloroform (PhChl) extraction method. ${ }^{(5)}$ However, these methods are lengthy, complex, and costly, and they have been shown to cause a degree of inhibition to DNA amplification with Taq polymerase. A number of alternative methods for sample processing for PCR have been reported, ${ }^{(6-9)}$ all tending toward a shorter and simpler procedure. However, inherent limitations, such as small volume sample, degrees of inhibition on DNA amplification, or poor stability of the processed sample, all call for an improved method for sample processing for PCR. We have devised a method of sample processing applicable to clinical blood samples to be tested by PCR. This method is based on selective lysis and washing of red blood cells (RBC) with the Roche Specimen Washing Solution (RSWS) and heat and/or heat-detergent (HD) treatment of the separated PBLs, to free DNA for amplification with Taq polymerase. This new method of blood sample processing for PCR is simpler, shorter, and more cost effective. It allows for longer storage of blood samples before processing (greater than 8 days in our tests) and is not inhibitory to DNA amplification. The extracted samples can be stored frozen for several week or months, without detectable loss in DNA amplification efficiency.

\section{MATERIALS AND METHODS \\ Clinical Blood Samples}

Replicate samples of HTLV-I/II-positive and -negative PBLs from individuals with a defined serological profile to HTLV-I/II were the gift of Drs. Celso Bianco and Maria Rios (New York City Blood Center). HIV-positive blood samples were contributed by Dr. José Girón, (Flushing, New York) and were from patients with antibodies to HIV or with AIDS. PBLs from healthy individuals, without detectable antibodies to retroviruses, were separated from blood samples from the Bergen County Blood Center (New Jersey).

\section{Plasmids}

Cloned HTLV-I sequences (pZW4G, 3.1 $\mathrm{kb})$ in pUC19 vector and HTLV-II sequences (pSK174.21) also in pUC19 were prepared in our laboratory and used in DNA amplification inhibition experiments and as positive controls.

\section{Reagents}

Heat-detergent extraction buffer consisted of $10 \mathrm{~mm}$ Tris (pH 8.3), $50 \mathrm{mM} \mathrm{KCl}$, $7.5 \mathrm{mM} \mathrm{MgCl}_{2}, 1.2 \%$ Nonidet P-40, and $1.2 \%$ Tween. PK extraction buffer was: Solution A-10 mm Tris (pH 8.3), $100 \mathrm{~mm}$ $\mathrm{KCl}, 7.5 \mathrm{~mm}^{\mathrm{MgCl}}{ }_{2}$. Solution $\mathrm{B}-10 \mathrm{~mm}$ Tris (pH 8.3), $7.5 \mathrm{~mm} \mathrm{MgCl}, 1 \%$ Nonidet P-40, 1\% Tween 20, and $200 \mu \mathrm{g} / \mathrm{ml}$ PK. PK was purchased from Boehringer Mannheim Co. RSWS is available from Roche Molecular Systems (1080 U.S. Highway 202, Branchburg, New Jersey 08876-1760). Lymphocyte separation medium (LSM) was purchased from Organon Teknika (North Carolina). 


\section{Cell Lines}

HTLV-I ${ }^{+}$MT-2 cells and HTLV-II ${ }^{+}$MO-T cells were provided by Dr. D. Volsky (Columbia University and St. Luke's Hospital, New York).

\section{Separation of PBLs}

1. By LSM gradient centrifugation: 2 $\mathrm{ml}$ of blood in buffered citrate solution was diluted with $2 \mathrm{ml}$ of PBS. It was then layered onto $3 \mathrm{ml}$ of LSM in a $15-\mathrm{ml}$ centrifuge tube (Corning, New York) and centrifuged at $400 \times g$ for $30 \mathrm{~min}$ at RT. The PBLs in the buffy coat were aspirated and washed twice in $5 \mathrm{ml}$ of PBS by centrifugation at $300 \times \mathrm{g}$ for $10 \mathrm{~min}$ at RT. Total time for separation of PBLs from 10 samples was about $90 \mathrm{~min}$.

2. By RBC lysis: To $0.5 \mathrm{ml}$ of blood in a 2-ml Sarstedt vial (Whatman, Newton, North Carolina) was added $1 \mathrm{ml}$ of RSWS, which was mixed by inverting the vial several times and incubated at RT for $5 \mathrm{~min}$. The mixture was then centrifuged at $7000 \times g$ for $3 \mathrm{~min}$ in an Eppendorf tabletop centrifuge and the supernatant was aspirated. The PBLs pellet was washed once in $1 \mathrm{ml}$ of RSWS by centrifugation as above. The supernatant was aspirated and the washed PBL pellet was extracted for DNA amplification. Total time for separating PBLs from 10 samples was about $15 \mathrm{~min}$.

\section{Digestion of PBLs with Proteinase $K$}

The PBL pellet was resuspended in $200 \mu \mathrm{l}$ of solution $A$ followed by the addition of $200 \mu \mathrm{l}$ of solution B to which $200 \mu \mathrm{g} / \mathrm{ml}$ PK was added at the time of processing. The sample was then incubated at $60^{\circ} \mathrm{C}$ for $1 \mathrm{hr}$ in a hot water bath, and the enzyme was heat-inactivated by heating at $95^{\circ} \mathrm{C}$ for $10 \mathrm{~min}$. The sample thus processed was used in $50-\mu$ l volumes for DNA amplification. Time required for sample extraction was $75 \mathrm{~min}$.

\section{Extraction of PBLs with HD Extraction Buffer}

The PBL pellets were resuspended in 400 $\mu l$ of HD extraction buffer in the 2-ml Sarstedt vials and tightly capped. They were then heated at $100^{\circ} \mathrm{C}$ for $10-15 \mathrm{~min}$ on boiling water or on a ThermoLyne Dri-Bath (Scientific Products, Illinois) set at $100^{\circ} \mathrm{C}$. Then they were tested for DNA amplification or they were stored frozen until ready for testing. Total time for sample extraction was $15 \mathrm{~min}$.

\section{DNA Amplification}

DNA amplification and detection of amplified DNA has been described. ${ }^{(10)}$ Briefly, $50 \mu$ l of sample were mixed with an equal volume of a PCR master mix containing 50 pmoles of biotin-labeled primers, dNTP, and 4 units of Taq DNA polymerase (Perkin-Elmer Cetus Instruments Amplitaq) in $10 \mathrm{~mm}$ Tris- $\mathrm{HCl}(\mathrm{pH}$ 8.3), $50 \mathrm{~mm} \mathrm{KCl}$, and $10 \%$ glycerol and subjected to thermocycling in a DNA Thermal Cycler (Perkin-Elmer Cetus Instruments). The biotin-labeled amplified DNA was hybridized to an oligonucleotide capture probe bound to wells in a microtiter plate. Bound amplified DNA was then reacted with an avidin-horseradish peroxidase conjugate and detected by a colorimetric reaction for peroxidase $\left(A_{450 \mathrm{~nm}}\right)$.

\section{Comparison Between the PK and HD Methods of DNA Extraction for PCR}

Replicates of PBL samples from eight HIV seropositive individuals and individuals at various stages of AIDS were separated by RBC lysis. Two sets of PBL samples were prepared. PBLs in one set were extracted by the PK digestion method. PBLs in the second set were extracted by the heat-detergent method as described in the Materials and Methods section. Fifty microliters of each sample from each of the two sets were amplified for HIV DNA and the amplified material was tested with the microtiter plate assay. A well-characterized HIV-positive sample and a sample from a healthy individual, without detectable antibodies to HIV, were similarly treated and used as positive and negative controls. The results are shown in Figure 1 where the ODs from the PK-extracted samples and those from the HD-extracted samples are shown side by side.

\section{Screening of Clinical Blood Samples}

To validate further our HD method of DNA extraction for PCR, we tested 38 clinical samples, well characterized for antibodies to HTLV-I/II. These samples had been tested for HTLV-I and HTLV-II DNA by PCR using the RBC lysis method to separate the PBLs, and their DNA was extracted by the PhChl method prior to amplification. Replicates of the same PBL samples were extracted by the PK method or by the HD method. The extracts were amplified for HTLV-I and HTLV-II DNA and the amplified material was tested with our microtiter plate assay. The results from the amplification of the PhChl, the PK-extracted, and the HD-extracted samples are compiled in Table 1.

\section{Sensitivity Assays}

Having established the feasibility, and having optimized the various parameters, of the HD method of blood sample processing, we moved on to finer comparative assays. In the following assays, we used the HTLV-I/II model and wellquantified target DNA in the form of plasmid or virus-positive cells from cell lines, such as MT-2 and MO-T cells, to

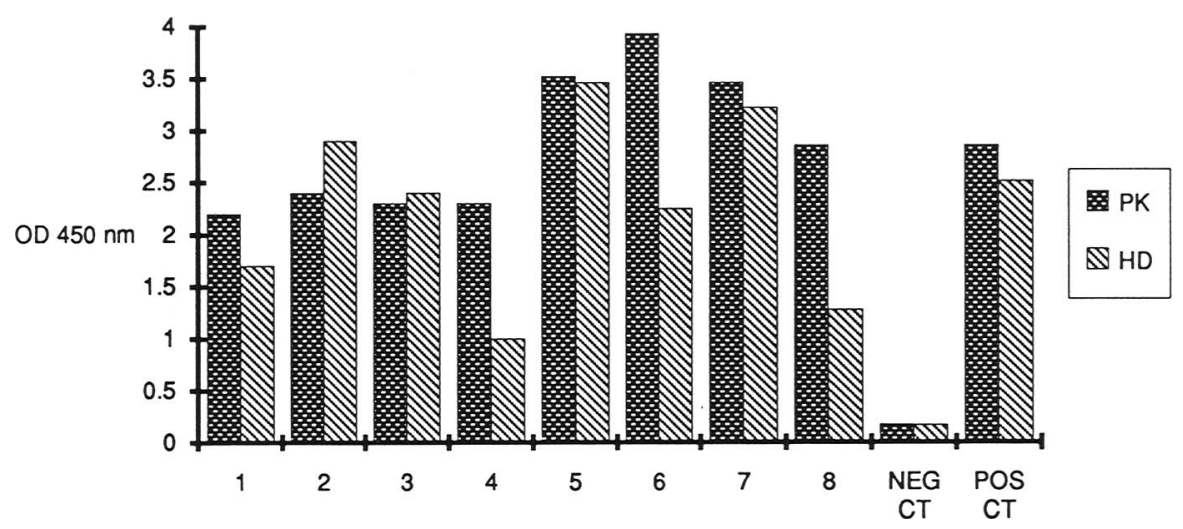

FIGURE 1 Screening of 8 HIV-positive PBL samples. Checkered bars represent PBLs separated by Ficoll-Hypaque and digested with Proteinase K. Striped bars represent PBLs separated with RSWS and extracted by the heat-detergent method. 
TABLE 1. Comparison of Efficiency in HTLV-I/II DNA Amplification by PCR Between Phenol-Chloroform, Proteinase K, and Heat-Detergent Extracts from 38 Clinical Blood Samples

\begin{tabular}{|c|c|c|c|c|c|c|c|c|c|c|}
\hline \multirow[b]{3}{*}{$\begin{array}{l}\text { Capture } \\
\text { probe }\end{array}$} & \multirow[b]{3}{*}{$\begin{array}{l}\text { Number of } \\
\text { samples tested }\end{array}$} & \multicolumn{9}{|c|}{ Method of sample extraction } \\
\hline & & \multicolumn{3}{|c|}{ chloroform-phenol } & \multicolumn{3}{|c|}{ proteinase $\mathrm{K}$} & \multicolumn{3}{|c|}{ heat-detergent } \\
\hline & & $\begin{array}{l}\text { number } \\
\text { positive }\end{array}$ & $\begin{array}{l}\text { percent } \\
\text { positive }\end{array}$ & $\mathrm{S} / \mathrm{N}^{\mathrm{a}}$ & $\begin{array}{l}\text { number } \\
\text { positive }\end{array}$ & $\begin{array}{l}\text { percent } \\
\text { positive }\end{array}$ & $\mathrm{S} / \mathrm{N}$ & $\begin{array}{l}\text { number } \\
\text { positive }\end{array}$ & $\begin{array}{l}\text { percent } \\
\text { positive }\end{array}$ & $\mathrm{S} / \mathrm{N}$ \\
\hline HTLV-I & 38 & 8 & 21 & $\mathrm{ND}$ & 8 & 21 & 40 & 10 & 26 & 23 \\
\hline HTLV-II & 38 & 5 & 13 & ND & 4 & 10 & 38 & 5 & 13 & 35 \\
\hline
\end{tabular}

Values were derived from OD readings at $450 \mathrm{~nm}$ from the microtiter plate assay on amplified DNA captured on complementary DNA probes.

${ }^{\text {a}} \mathrm{S} / \mathrm{N}$ indicates signal-over-noise ratio calculated on the mean of the OD.

compare the sensitivity of the two methods. Suspension cultures of the MT-2 cells and MO-T cells were carried out in our lab. Dilutions of these cells were made in a background of normal PBLs in PK buffer containing $100 \mu \mathrm{g} / \mathrm{ml}$ PK or in the enzyme-free HD extraction buffer. The normal PBL concentration was $2.5 \times$ $10^{6}$ cells $/ \mathrm{ml}$. The virus-positive cells were spiked in the normal PBL background diluent at concentrations of $2,5,20,50$, and 100 cells $/ 50 \mu l$, which was our PCR assay volume. HTLV-I and HTLV-II plasmids in normal PBL diluent were used as positive controls at 20 copies per assay. Plain diluent with a normal PBLs background was used as a negative control.

The virus-positive cell samples and controls in the PK diluent were incubated for $60 \mathrm{~min}$ at $60^{\circ} \mathrm{C}$, then at $95^{\circ} \mathrm{C}$ for $10 \mathrm{~min}$ to inactivate the enzyme. Those in the $\mathrm{HD}$ diluent were heated at $100^{\circ} \mathrm{C}$ for $15 \mathrm{~min}$. They were then all amplified for HTLV-I DNA or for HTLV-II DNA and plate-assayed on homologous capture probes. The results from the HTLV-I as- say are shown in Figure 2 where the ODs are plotted against the number of cells per assay. The data from the HTLV-II assay (not shown) were similar to those of the HTLV-I assay. Results from the plasmid positive control (PLSMD) and zero cell control (0) are also shown.

\section{DNA Amplification Inhibition Assay}

Normal PBL diluents were prepared as described above. HTLV-I or HTLV-II plasmids were spiked into the normal cell suspension at concentrations of 5,10 , 15,20 , and 30 copies per assay. Three sets of plasmid dilutions were thus prepared for each of the two plasmids-one set in the PK normal PBL buffer, and two sets in the HD normal PBL buffer. The plasmid dilution set in the PK buffer was incubated for $1 \mathrm{hr}$ at $60^{\circ} \mathrm{C}$ and then heated at $100^{\circ} \mathrm{C}$ for $30 \mathrm{~min}$. Of the two plasmid dilution sets in the HD extraction buffer, one was heated at $100^{\circ} \mathrm{C}$ for $30 \mathrm{~min}$, the other was heated at $100^{\circ} \mathrm{C}$ for $15 \mathrm{~min}$. MT-2 or MO-T cells in nor-

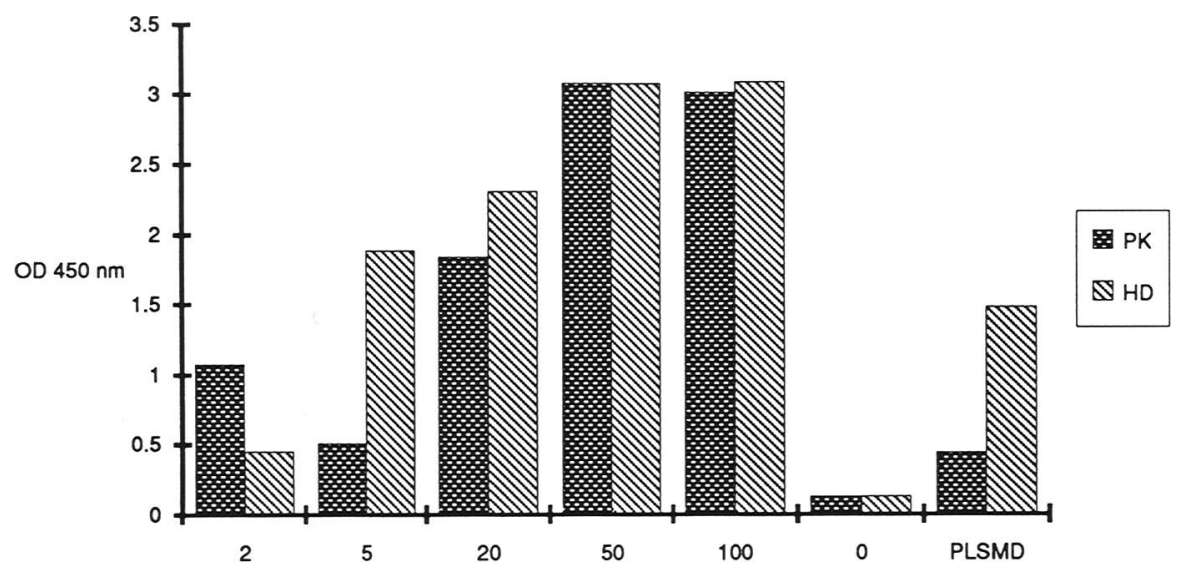

FIGURE 2 MT- 2 cells in normal PBL-PK or -HD buffer; PK- or HD-extracted. Numbers on the $x$ axis are the number of MT-2 cells per assay. HTLV-1 plasmid DNA (PLSMD) was used as the positive control at 20 copies per assay.

mal PBL HD extraction buffer were heated at $100^{\circ} \mathrm{C}$ for $15 \mathrm{~min}$ and used as positive control at a cell concentration of $2 \times 10^{3} / \mathrm{ml}$ equivalent to 100 cells per assay. The zero plasmid dilution was the negative control.

All samples were amplified for HTLV-I or HTLV-II DNA and assayed in a microtiter plates assay using homologous capture probes. The results are shown in Figure 3 , where the ODs are plotted against the number of copies of plasmid DNA per assay. Here again, data from the HTLV-II assay (not shown) were similar to those of the HTLV-I assay.

\section{RESULTS AND DISCUSSION}

The procedure for blood sample processing described in this paper fulfills the need for a shorter, simpler, and more cost-effective method of PBLs separation and extraction for DNA amplification by PCR. The results from our validation experiments show that target DNA in PBLs, separated by RBC lysis, can be amplified very effectively. In Figure 1, the ODs from eight $\mathrm{HIV}^{+} \mathrm{PBL}$ samples separated by RBC lysis and HD-extracted, are shown alongside ODs from PBLs from the same blood samples, part of which had been separated on Ficoll-Hypaque and digested with PK. All of the samples amplified for HIV DNA equally well after extraction by either the HD or the PK methods. Furthermore, results from feasibility studies revealed that we could effectively separate PBLs from blood samples and amplify the viral DNA by RBC lysis and $\mathrm{HD}$ extraction at 2, 3, and 8 days after drawing (data not shown ).

Results from additional validation assays on 38 clinical samples are shown in Table 1. As stated in Materials and Methods, these PBL samples had been tested by PCR for HTLV-I and HTLV-II DNA af- 


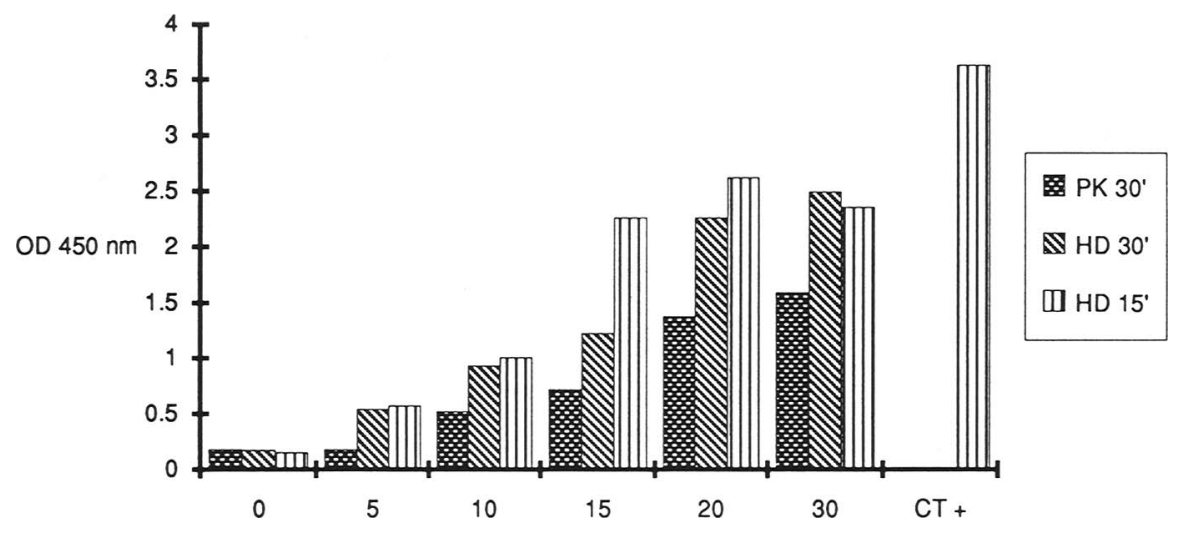

FIGURE 3 HTLV-1 DNA in normal PBL-PK or -HD diluent. Heated at $100^{\circ} \mathrm{C}$ for $30 \mathrm{~min}$ or for 15 min. Numbers on the $x$ axis are copies of plasmid DNA per assay. The positive control $\left(\mathrm{CT}^{+}\right)$was an HD extract of MT- 2 cells at 100 cells per assay.

ter separation by RBC lysis, PK digestion, and DNA extraction with PhChl. Replicates of these PBL samples were then extracted by the PK method or by the HD method and the results compared. Out of 38 samples, 15 (39.5\%) that were HD extracted were found to be virus-positive compared to $13(36.8 \%)$ of the PhChlextracted samples and $12(34.2 \%)$ of the PK-extracted samples. Ten of the HD-extracted, virus-positive samples were positive for HTLV-I and 5 were positive for HTLV-II. Among the 12 virus-positive PK-extracted samples, 8 were positive for HTLV-I and 4 were positive for HTLV-II. Two samples that were amplified after HD extraction were not amplified after extraction by the PK method. Among the 13 virus-positive, PhChl-extracted samples, 8 were positive for HTLV-I, and 5 were positive for HTLV-II. Two samples were not amplified after extraction by PhChl or by PK, but were amplified after extraction by the HD method.

Virus-positive samples extracted by the HD method gave generally higher OD readings after DNA amplification and plate assay, compared to the same samples extracted by the PK method. This was more clearly observed in samples tested for HTLV-II. Results from the HTLV-I plate assay showed a slightly higher background reading with the HD extracts. However, this low background noise could be eliminated by incorporating $1 \%$ Tween 20 in the wash buffer at the final wash of the microtiter plate. The cutoff point for these samples was set at an OD value of 0.25 . As expected, the signal-to-noise ratio for the HD-extracted samples of the HTLV-I series was lower than that of the PK-extracted sam- ples, mainly because one of the samples was a low positive when HD extracted with an OD reading of 0.37 , but was not amplified after PK or PhChl extraction. The signal-over-noise ratios for the HTLV-II series of the PK or HD extracts are quite comparable, showing values of 38 and 35 , respectively.

Data from sensitivity assays, using dilution panels of MT-2 and MO-T cells, further confirmed the effectiveness of the HD method of cell extraction for PCR. The results from these assays are shown in Figure 2, where ODs are plotted against the cell dilution as the number of virus-positive cells per amplification. Here again the ODs for both methods are quite comparable. As stated in Materials and Methods, the positive controls in these assays were HTLV-I plasmid DNA at a concentration of 20 copies per assay. Again the plasmid dilutions were treated exactly as the test samples. A phenomenon worth noting is that the HD-treated plasmid positive control for the MT-2 cell dilution gave a significantly higher signal than the same plasmid preparation that was PK treated. Similar results were obtained using the MO-T cells (data not shown).

Additional experiments in our lab studying this reduction in signal in PKtreated samples, using plasmid dilutions at low copy number, gave similar results. The DNA amplification inhibition assays here reported were a scale-up of preliminary experiments using now a larger number of HTLV-I plasmid DNA dilutions. The concentrations of virus plasmid DNA in the normal cell diluents, as stated above, were $5,10,15,20$, and 30 copies per assay. The PK-treated set of plasmid DNA dilutions was inactivated for $30 \mathrm{~min}$ at $100^{\circ} \mathrm{C}$ to insure complete inactivation of the digestive enzyme. One set of the HD-treated plasmid DNA dilutions was also heated for $30 \mathrm{~min}$ at $100^{\circ} \mathrm{C}$ for proper comparison. The second set of the HD-treated plasmid DNA dilutions was heated for $15 \mathrm{~min}$ at the same temperature. The results of these experiments are shown in Figure 3, where the ODs from the plate assay are plotted against the copy numbers of plasmid DNA per assay. There was no significant difference in ODs between the HD-treated samples heated at $100^{\circ} \mathrm{C}$ for $15 \mathrm{~min}$ and those heated for $30 \mathrm{~min}$; an exception was made of dilution 15, which could be attributed to experimental variation. However, the PK-treated plasmid DNA samples gave significantly lower ODs compared to either one of the HD-treated plasmid DNA dilution series. This inhibition phenomenon in PKtreated samples was reproducible and was more apparent at low copy number of either HTLV-I or HTLV-II plasmid DNA. This would be expected due to the fact that amplification of target DNA proceeds at an exponential rate and that beyond a given number of target copies and a number of thermal cycles the signal becomes too high and there can be a wide variability in the number of amplicons generated during the temperature cycles.

The observed reduction in signal generation associated with the PK method of DNA extraction could give false-negative results with samples having a low copy number of target DNA. A case in point is a sample we tested for HTLV-I/II, not listed in the Materials and Methods section. This sample was negative after PK extraction and DNA amplification, with an $\mathrm{OD}$ reading of 0.077 from the microtiter plate assay. However, it became positive when diluted 1:2 in PK buffer without PK, with an OD reading of 1.31 . It reverted back to negative after further dilution to $1: 5$ with an OD of 0.21 . The HD extract of the same sample, on the other hand, gave consistently high readings, undiluted or after $1: 2$ and 1:5 dilution in HD buffer with OD readings of 3.97 , 3.99 , and 3.98 , respectively. Since there are reports of sample-associated Taq polymerase inhibitors found only in some samples, ${ }^{(11)}$ it is uncertain at this time whether inhibition of DNA amplification in the PK extract of this sample was related to the PK extraction method 
or whether it was due to some sampleassociated Taq polymerase inhibitor. If the inhibitor was sample associated, its action was clearly obviated by the HD treatment. False-negative samples have been encountered infrequently in our lab after PK extraction and the signal was recovered by diluting the sample or by HD-extracting PBLs.

Taken together, these data show that the HD method of blood sample processing for PCR presents advantages over the traditional methods of PBLs separation by Ficoll-Hypaque and DNA extraction by PK digestion. It is simpler, shorter, more cost-effective (the cost of the RSWS is only a small fraction of that of LSM and the duration of the procedure is reduced from $2 \mathrm{hr}$ and $45 \mathrm{~min}$ for the Ficoll separation of PBLs and PK extraction to 30 min for the RBC lysis and HD extraction). More importantly, the RBC lysis-HD extraction method is not inhibitory to DNA amplification, therefore conferring greater sensitivity to the PCR test. It also allows effective PBLs separation and DNA amplification of relatively old blood samples. PBL separation from such blood samples is very difficult to perform using the Ficoll-Hypaque method. Additionally PBL samples that are HD-extracted can be stored frozen for a prolonged length of time without apparent loss in amplification efficiency.

\section{ACKNOWLEDGMENTS}

We wish to thank Drs. Celso Bianco and Maria Rios at the New York Blood Center for their HTLV-I/II-characterized PBL samples. We thank Ket Kung, Wendy Schilling, Bonnie McGhee, and Tatjana Frenkl for their valuable assistance; Zhuang Wang for preparing the HTLV-I/ II plasmid DNA; and Dr. Richard Respess for valuable discussions. We thank Victoria Williams for her secretarial help.

\section{REFERENCES}

1. Mullis, K.B., F.A. Faloona, S.J. Scharf, R.K. Saiki, G.T. Horn, and H.A. Erlich. 1986. Specific enzymatic amplification of DNA in vitro: The polymerase chain reaction. Cold Spring Harbor Symp. Quant. Biol. 51:

2. Boyum, A. 1968. Isolation of mononuclear cells and granulocytes from human blood. Scand. I. Clin. Lab. Invest. 21 (Suppl. 97): 77. 3. Fotino, M., E.J. Merson, and F.J. Allen. 1971. Micromethod for rapid separation of lymphocytes from peripheral blood. Ann. Clin. Lab. Sci.
1: 131-133. 4. Ausubel, F.M. et al. 1987. Current protocols in molecular biology. Wiley, New York.

5. Bin, N. and D.W. Stafford. 1976. Isolation of high molecular-weight DNA. Nucleic Acid Res. 3: 2303.

6. Singer-Sam, J., R. Tanguay, and A.D. Riggs. 1989. Use of Chelex to improve the PCR signal from a small number of cells. Amplifications 3: 11.

7. Chen, S. and G.A. Evans. 1990. A simple screening method for transgenic mice using the polymerase chain reaction. Biotechniques 8: 32-33.

8. Higuchi, R. 1989. Rapid, efficient DNA extraction for PCR from cells or blood. Amplifications 2: 1-3.

9. Miller, S.A., D.D. Dykes, and H.F. Polesky. 1988. A simple salting out procedure for extracting DNA from human nucleated cells. Nucleic Acids Res. 16: 1215.

10. Whetsell, A.J., J.B. Drew, G. Milman, R. Hoff, E.A. Dragon, K. Adler, J. Hui, P. Otto, P. Gupta, H. Farzadegan, and S.M. Wolinsky. 1992. Comparison of three nonradioisotopic polymerase chain reaction-based methods for detection of human immunodeficiency virus type 1. J. Clin. Microbiol. 30: 845-853.

11. Coutlé, F., P. Saint-Atoine, C. Olivier, A. Kessous-Elbaz, E. Voyer, F. Berrada, P. B́gin, L. Giroux, and R. Viscidi. 1991. Discordance between primer pairs in the polymerase chain reaction for detection of human immunodeficiency virus type 1: A role for $T a q$ polymerase inhibitors. $J$. Infect. Dis. 164: 117-118.

Received May 13, 1992; accepted in revised form June 17, 1992. 


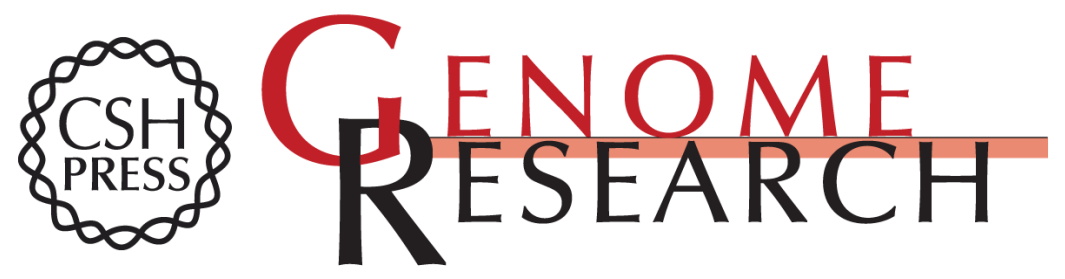

\section{Improved blood sample processing for PCR.}

D Casareale, R Pottathil and R Diaco

Genome Res. 1992 2: 149-153

Access the most recent version at doi:10.1101/gr.2.2.149

References This article cites 9 articles, 1 of which can be accessed free at:

http://genome.cshlp.org/content/2/2/149.full.html\#ref-list-1

\section{License}

Email Alerting Receive free email alerts when new articles cite this article - sign up in the box at the Service top right corner of the article or click here.

\section{Affordable, Accurate Sequencing.}

To subscribe to Genome Research go to: https://genome.cshlp.org/subscriptions 